Ina Ehnert, Wes Harry

\title{
Recent Developments and Future Prospects on Sustainable Human Resource Management: Introduction to the Special Issue ${ }^{* *}$
}

In this editorial the previous and current state of studies in the subject of sustainability are considered and the role of HRM examined. Particular attention is drawn to the range of definitions of 'sustainability' and to prior approaches to Sustainable HRM. The difficulties of studying the complexities of the topics especially the varying perspectives from geographical locations and from practice and academia are observed. Meanwhile the opportunities for academic research to add value to the world of practice are identified. The editors then outline the contributions by the authors of the three papers and an extended book review that make up the Special Edition. Finally, there are suggestions for the course of future research on this increasingly important topic - for academics, for practitioners and for humanity in general.

Key words: Human Resource Management, sustainability, Sustainable HRM, literature review (JEL: M12, M14)

* Prof. Dr. Ina Ehnert is Professor of Human Resource Management with a specialization in Corporate Social Responsibility and sustainability, Louvain School of Management, Louvain-la-Neuve, Belgium. E-mail: ina.ehnert@uclouvain.be.

Dr. Wes Harry is Visiting Professor at Chester Business School, University of Chester, Parkgate Road. Chester. CH1 4BJ, UK. E-mail: w.harry@chester.ac.uk.

** Article received: August 30, 2012. 


\section{Introduction}

Since the United Nation's World Commission on Environment and Development (WCED or 'Brundtland Commission') published its report in 1987 (WCED, 1987), the notions of sustainability and sustainable development have attracted increasing interest in the field of business and management and recently also of human resource management (HRM). The objective of the Brundtland report was to develop an agenda for global change and a common future for mankind and has been concerned with the question of how to advance societal and economic development without endangering natural living conditions for the majority of humanity.

Today, the political and societal sustainability debate focuses more than ever around the challenges arising from, the natural, social and financial resources of the world being insufficient for a third of the current population of human beings, to have the material standards of living of the richest people who, possibly, make up barely $10 \%$ of the overall numbers. Second, the debate also relates to resource-intensive lifestyle of industrialized countries and our contribution to resource depletion. Third, the sustainability debate at the corporate and HRM level deals with practices and strategies that produce significant impact on an organization's natural and social resources and environments which then influences the organization's and HRM's future management conditions and business environment.

Businesses being wasteful with resources (natural and human among others) might have made sense when there appeared to be a limitless supply. For example, many people 'benefiting' from the asset bubble of property and commodities in the first decade of the $21^{\text {st }}$ century did not worry about the unsustainability of continuing large scale consumption of goods, services and debt until the financial and economic crises started in 2007. The consequences of such consumption without balancing renewal or reproduction had widespread implications for current and future generations especially in Europe and the USA. HRM contributed to the bubble through rewards given for short term illusions of performance which turned out to not reflect the reality of value creation and for plundering pension resources of current and former employees so that the remainder is insufficient to meet the pension commitments. But now that we have more clarity of the global limits and restrictions businesses seem to be more willing to look at sustainability.

The recent interest in integrating the idea of sustainability into mainstream economic thinking is therefore not surprising although, in the past, actors seem to become aware of the relevance of sustainability thinking in particular or, perhaps only, in situations of a serious crisis or resource shortages (see Ehnert, 2009a). Situations of crisis or resource shortages, however, are no guarantee for sustainable business behavior. On the contrary we also observe that in times of crisis and focus upon immediate survival then sustainability is discarded which means that current generations of decision-makers in organizations endure at the cost of overusing resources thus depriving those who follow after.

In spite of the increasing interest in practice and in scholarship of how to make organizations not only economically but also ecologically, socially etc. sustainable (e.g. Bansal, 2005; Hahn \& Figge, 2011), research on sustainability and HRM (often called 
'Sustainable HRM') has, until recently, remained surprisingly scarce (Cohen et al., 2012; Pfeffer, 2010). It is only in the past decade that we observe an increase in publications on sustainability and HRM and many HR colleagues seem to remain critical of the concept.

Why, however, is sustainability relevant for the HR function and how can this concept be fruitfully defined and applied? There are two major lines of arguments to support the importance of a sustainability perspective on HRM. The first line of argument refers to the relationship of the organization to its economic and social environments and is mainly linked to the societal and ecological sustainability debate (macro level). The key argument here is that the HRM field can (or should) no longer neglect the societal discourse on sustainability and corporate sustainability because this is dealt with in practice and that HRM could make important contributions to corporate sustainable development (e.g. Cohen et al., 2012; Jackson et al., 2011). The second line of arguments addresses the internal elements and relationships of an HRM system and is linked to the individual and HRM level debate (meso and micro levels). This debate is linked to the observation of scarce human resources, of aging workforces and of increasing work-related health problems and the argument is that fostering the sustainability of the HRM system itself becomes a 'survival strategy' for organizations dependent on high quality employees (e.g. Ehnert, 2009a; Zaugg, 2009).

The objective of this special issue is to provide contributions to both streams as an introduction into research on Sustainable HRM and to encourage future research and debates on this issue. This editorial is structured to guide the reader through the key issues. As the academic debate on Sustainable HRM is a relatively recent one, we start by introducing briefly in the difficulties of defining sustainability and in the literatures on sustainability and HRM. Next, we present short summaries of the contributing articles in this Special Issue. Finally, we propose how future research could develop from existing studies of sustainability and HRM.

\section{Defining sustainability for HRM}

The Brundtland Commission defined 'sustainable development' as a 'development that meets the needs of the present without compromising the ability of future generations to meet their own needs" (WCED, 1987: 43) and asserted that sustainable development at the societal level requires simultaneous realization of an economic, ecological, and social dimension of sustainability (WCED, 1987). Prompted by the Brundtland Commission's societal definition of sustainable development, many alternative definitions of corporate sustainability have emerged (e.g. Gladwin et al., 1995). Hahn and Figge (2011) highlight that "there seems to be some implicit pragmatic consensus that corporate sustainability (CS) refers to some composite and multi-faceted construct that entails environmental, social, and economic organizational outcomes (p. 327)". However, research on CS still struggles with providing a practical definition on corporate sustainability and with one that goes beyond the mainstream win-win-win thinking in the field (see Hahn \& Figge, 2011). While we do not neglect that win-winwin situations are possible in some organizations and some contexts, we assume that for the majority of organizations it will not be so easy to create economic efficiency, 
ecological, social and human sustainability simultaneously without a fundamental change in their business strategy and organizational culture.

This topic of lack of wide agreement on the definition of CS does also have an impact on the emerging research on Sustainable HRM and is therefore one which is returned to throughout this edition of the journal. We also highlight paradoxes, dilemmas and tensions that arise when implementing sustainability practices and strategies in practice are often neglected, especially in the efficiency-oriented debate (see also Hahn \& Figge, 2011). For the purpose of our Special Issue, we are interested in selective examples for definitions which illustrate the complexity of the topic and which may potentially be applicable from an HRM perspective (see Table 1).

Table 1: Sustainability definitions (examples)

\begin{tabular}{|c|c|c|}
\hline Reference & Sustainability definition & Rationale \\
\hline $\begin{array}{l}\text { Dyllick \& } \\
\text { Hockerts } \\
\text { (2002: 131) }\end{array}$ & $\begin{array}{l}\text { Corporate sustainability is "defined as meeting the needs of a firm's } \\
\text { direct and indirect stakeholders (such as shareholders, employees, } \\
\text { clients, pressure groups, communities etc.), without compromising } \\
\text { its ability to meet the needs of future stakeholders as well." }\end{array}$ & $\begin{array}{l}\text { Grow corporate economic, social } \\
\text { and environmental capital base; } \\
\text { understand organizational suc- } \\
\text { cess as the 'triple bottom line' } \\
\text { (Elkington, 1994) }\end{array}$ \\
\hline $\begin{array}{l}\text { Boudreau \& } \\
\text { Ramstad } \\
(2005: 129)\end{array}$ & $\begin{array}{l}\text { "achieving success today without compromising the needs of the } \\
\text { future" }\end{array}$ & $\begin{array}{l}\text { Grow human capital; understand } \\
\text { organizational success beyond } \\
\text { the financial bottom line }\end{array}$ \\
\hline $\begin{array}{l}\text { Costanza, } \\
\text { Daly, \& B } \\
\text { artholomew, } \\
\text { (1991: 8), } \\
\text { cited from } \\
\text { Gladwin et al., } \\
\text { (1995: } 877)\end{array}$ & $\begin{array}{l}\text { "Sustainability is a relationship between dynamic human economic } \\
\text { systems and larger dynamic, but normally slower-changing ecolog- } \\
\text { ical systems, in which (a) human life can continue indefinitely, (b) } \\
\text { human individuals can flourish, and (c) human cultures can devel- } \\
\text { op; but in which effects of human activities remain within bounds, } \\
\text { so as not to destroy the diversity, complexity, and function of the } \\
\text { ecological life support system." }\end{array}$ & $\begin{array}{l}\text { Functional systems view; main- } \\
\text { taining the ecological life support } \\
\text { systems; no socio-economic sys- } \\
\text { tems without eco-systems. }\end{array}$ \\
\hline $\begin{array}{l}\text { Docherty et al. } \\
(2002: 12)\end{array}$ & $\begin{array}{l}\text { "Sustainability - as we understand it - encompasses three levels: } \\
\text { the individual, the organizational and the societal. Sustainability at } \\
\text { one level cannot be built on the exploitation of the others. These } \\
\text { levels are intimately related to the organization's key stakeholders: } \\
\text { personnel, customers, owners and society. [...] A prerequisite for } \\
\text { sustainability at the system level (individual, organizational or soci- } \\
\text { etal) is to achieve a balance between stakeholders' needs and } \\
\text { goals at different levels simultaneously." }\end{array}$ & $\begin{array}{l}\text { Multi-level construct and interde- } \\
\text { pendencies between different } \\
\text { levels; focus on human resource } \\
\text { regeneration, development. }\end{array}$ \\
\hline $\begin{array}{l}\text { Ehnert } \\
\text { (2009a) based } \\
\text { on Müller- } \\
\text { Christ \& } \\
\text { Remer (1999) }\end{array}$ & $\begin{array}{l}\text { Sustainability = Resource consumption/Resource regeneration }>/= \\
1 \text { (Sustainability is the balance of resource consumption and re- } \\
\text { source regeneration) }\end{array}$ & $\begin{array}{l}\text { Functional (eco-) systems view. } \\
\text { Focus on human resource re- } \\
\text { generation, development and on } \\
\text { maintaining the resource base } \\
\text { and relationships (substance) in- } \\
\text { side and outside the organiza- } \\
\text { tion. }\end{array}$ \\
\hline
\end{tabular}

Source: Own elaboration.

We differentiate process-oriented and content-oriented definitions of sustainability as well as varying rationales, ethical and rational ones, about why sustainability is relevant for organizations and HRM (Ehnert, 2009a; see also the paper from Kozica \& Kaiser in this special issue). The key economic interpretations of sustainability refer to redefining the understanding of corporate success (see Table 1). Understanding success as the financial performance maximization is extended by awareness that ecological and 
social performance are also (if not equally important) for an organization's long-term survival. Hence, some authors translate sustainability as a call to grow the corporate economic, environmental, social and human capital base (see Table 1). Today's investments for the future are often justified by considering the 'needs' of future generations although these needs are difficult to determine and when immediate survival is the imperative to think, then, of the future can seem superfluous or meaningless. However, this concern for future generations is an important question because the answer has an impact on what is going to be sustained.

Recent management publications are clearer about what needs to be sustained (see Table 1) as life on earth can be imagined without humans but not, in logic, without functioning life-support systems. These broader and process-oriented definitions of sustainability refer to complex interrelations and dependencies between ecological and socio-economic systems. The socio-economic systems do not operate in a vacuum but need to control or manage their impact on life-supporting systems. The implications for organizations and HRM are logical however difficult to operationalize for individual decision-making processes. This is why in practice and research, the threepillar model of sustainability is so popular, although it is neglecting some of the complexities (see Hahn \& Figge, 2011) with the risk of reducing sustainability as merely to a 'means' to financial 'ends' (e.g. eco-friendly behavior as a business opportunity) or a means to social ends (e.g. potential future needs), instead of an end in itself (e.g. maintaining life-supporting systems).

Beyond the mainstream debate, an alternative definition of sustainability has been proposed through understanding sustainability as a rationale to balance consumption and regeneration of corporate resources (see Table 1). The idea is that if companies engage themselves in regenerating and developing the resources that they themselves consume today and will need in the future - by maintaining the systems and relationships from where these resources originate from - this can be called sustainability and lead to sustainable business behavior. The attractiveness of this substance-oriented formula is that it appears to be a simple and relatively easy application for all management choices and useful for HRM (see Ehnert, 2009a; see also the papers in this special issue). Ehnert (2009a) has pointed toward ethical limitations of this rationale.

We, therefore, conclude that a generic call for building ecological, social and human capital or resources might not lead to the desired consequences within our current economic system. As a proverb says 'Give a man a fish and you feed him for a day. Teach a man how to fish and you feed him for a lifetime'. However, sustainability is not about learning 'how to fish' but about understanding what the fish itself needs to grow and reproduce itself - and to make sure that these conditions are sustained. In the long run, sustainability raises the need to re-discuss the purpose of the organization (e.g. de Woot, 2005) and the notion of success (e.g. Hahn \& Figge, 2011) and last but not least to re-discuss the role of HRM - a useful debate that has started in research on Sustainable HRM.

\section{Research on sustainability and HRM}

In the history of research on Sustainable HRM we are still at the pioneering if not emerging phase. The work on Sustainable HRM is exploratory and so far has had the 
goal of describing the phenomenon of sustainability and its usefulness for HRM. The initial contributions appeared at the end of the 1990ies in Germany (e.g. Müller-Christ \& Remer, 1999), in Switzerland (e.g. Zaugg et al., 2001) and in Australia (e.g. Gollan, 2000; Wilkinson et al., 2001). The primary contribution of the first book chapters, studies and journal articles was to point out the importance of sustainability for HRM, to provide preliminary ideas about how sustainability could be linked to HRM and to give this research the label 'Sustainable HRM'. This early writing was inspired by prior research on environmental management (EM) and CS, but also by research on HRM in the human relations tradition and the Harvard approach (e.g. Beer et al., 1984). It was based on the observations that not only natural resources but also people are often scarce resources that companies need to exist (e.g. Müller-Christ \& Remer, 1999; Wilkinson et al., 2001), that existing approaches to deal efficiently and effectively with resources and human resources in organizations are often too short-term oriented and insufficient (e.g. Wilkinson et al., 2001), that people in organizations are 'consumed' rather than 'reproduced' and that Sustainable HRM, i.e. dealing with people in organizations in a sustainable way, could be a source of competitive advantage in tight labor markets (e.g. Zaugg et al., 2001).

These initial writings provided first definitions of Sustainable HRM. For example, Zaugg and colleagues (2001) defined Sustainable HRM as "long term socially and economically efficient recruitment, development, retainment and disemployment of employees" (p. II). Müller-Christ \& Remer (1999) defined Sustainable HRM as "what organizations themselves have to do to in their environments to have access to highly qualified people in the future (p. 76; translated from German by the authors)". Meanwhile Gollan (2005) defined "human resources sustainability in terms of the capacity of organisations to create value, thereby having the ability capacity to regenerate value and renew wealth through the application of human resource policies and practices" (p. 26). Looking at these various definitions of Sustainable HRM, we can observe different assumptions about the goals of Sustainable HRM and diverse understanding of the term sustainability. At that time, most definitions of Sustainable HRM were related to a long-term understanding of corporate success and organizational viability and future-orientation is indeed one of the important links of sustainability to (Strategic) HRM (see Ehnert, 2009a).

The Swiss approach relied first upon empirical research on the understanding of sustainability and HRM in HR practice (Zaugg et al., 2001) and has been extended at a later stage into a systematic conceptualization of Sustainable HRM based on conceptual and qualitative case research (Zaugg, 2009). This research focused on economic and social or human sustainability but not on ecological sustainability of the firm. Very similarly, the Australian approach to Sustainable HRM, developed mainly by Gollan $(2000,2005)$, focuses on human resources sustainability within the paradigm of high involvement works systems. The German approach to Sustainable HRM was developed in the context of a sustainable resource management approach focusing on economic, ecological and human resource sustainability of the firm and informed by resource dependence, system's, co-evolution and ecological theory (Müller-Christ, 2001). The key contribution of this approach was to point out the dependence of organizations on the survival of their organizational environments and that a survival strategy 
of the organization is to invest in the system's relationships with its environments (Müller-Christ, 2001):

"All costs that contribute to improving the resource relationships between organisations and their environments are at the same time investments in a functioning sustainable resource and household community which sustains the common resource base" (MüllerChrist 2001: 345; translated from German by Ehnert, 2009: 52).

This substance-oriented approach has been extended and substantiated by Ehnert (2006, 2008, 2009a/b, 2010, 2011, 2012) from a paradox theory perspective and is based on the assumption that sustainability, if it is defined as balancing consumed and reproduced resources, brings about paradoxical choices situations and tensions for actors in Sustainable HRM that need to be actively dealt with and that can be a source for innovation and change (see the article from Kozica \& Kaiser in this Special Issue).

In parallel to these first publications on Sustainable HRM, the importance of the sustainability idea for people management issues has been observed in a closely related field called 'sustainable work systems' with an origin in organizational behavior and industrial relations and with a strong empirical tradition. Scholars in this area, and in particular Peter Docherty, Mari Kira, Abraham (Rami) Shani and colleagues, explore how conceptually and empirically organizations can develop and sustain work systems which are economically, socially and ecologically sustainable and which foster in particular human regeneration, health and development (e.g. Docherty et al., 2002, 2009; Kira, 2002; Moldaschl \& Fischer, 2004). This focus on human regeneration, health and development is where sustainable work systems has informed and overlaps with the works on Sustainable HRM.

In a second 'wave' of pioneering research, scholars making early contributions have researched the link between sustainability and HRM more systematically and others have offered additional views by applying the idea of sustainability to different HR problem areas such as a sustainable HR strategy for reducing the undesired impact ('externalities') of downsizing activities (Mariappanadar, 2003, 2012a/b; Wilkinson, 2005), the potential of sustainability as a new paradigm for HRM and talent management (Boudreau \& Ramstad, 2005), the importance of human sustainability (Pfeffer, 2010; Scholz \& Müller, 2010; Zink, 2008) and a stakeholder theory approach to Sustainable HRM (Guerci, 2011) and a first edited volume on sustainability and HRM (Clarke, 2011). Noteworthy are the contributions on human sustainability by Pfeffer (2010) who asserts that human sustainability is neglected in the overall societal debate on greening and sustainability. In addition the contribution by Guerci (2011) offers a stakeholder approach on Sustainable HRM with case material from Italian companies. The volume edited by Clarke (2011) is a collection of 10 individual chapters on the topic of HRM and sustainability and seeks to encourage its readers to think beyond existing paradigmatic boundaries in HRM and to make sense of the meaning of sustainability for their particular contexts. This second wave of pioneering research is characterized by a large number of single authored contributions, working independent from each other and by a consolidation of early approaches. This research is mainly informed by the research areas CS, (Strategic) HRM, human factors (ergonomics) and sustainable works systems. 
Today, we find ourselves in a 'third wave' of publications on sustainability and HRM where researchers are starting to connect themselves, to work in interdisciplinary teams on Sustainable HRM and where the focus shifts from the interest in Sustainable HRM systems towards the societal debate of sustainability. There is also a broader understanding of the role of HRM in making organizations not only economically and socially but also ecologically sustainable and responsible (e.g. Cohen et al., 2012; Clarke, 2011; Ehnert et al., forthcoming; Muller-Camen et al., 2008). However, we observe that most authors omit to explore sustainability dimensions in their entirety. Instead, competing concepts emerge such as 'Green HRM' focusing on environmental sustainability accepting the dominance of economic performance maximization (e.g. Jabbour \& Santos, 2008; Jackson et al., 2011; Jackson \& Seo, 2010) and 'Socially Responsible HRM' (e.g. Cohen, 2010) focusing on social sustainability and Corporate Social Responsibility (CSR). This development of specializing on two dimensions of sustainability rather than three or four means that we are in a period where competing ideas emerge on the means to have sustainability used constructively for HRM and methods of use in practice (which might be different).

At the same time, we observe an increasing interest within practice and scholarship in the societal debate about sustainable development. For example, 'Green Management Matters' has been the annual theme of the world's largest association for management scholars, the Academy of Management, from 2009; the Network of German-language Professors of Business \& Management (VHB) followed in 2011 by dedicating its annual theme to 'Sustainability - Entrepreneurial Actions and Global Responsibility', and since 2010, the Strategic HRM workshop organized by EIASM, Brussels, fosters a sub-track on Sustainable HRM. The first special issue on Sustainable HRM - interested also in the ecological dimension of sustainability - appeared in the German journal uwf (Umweltwirtschaftsforum) in 2008. In parallel to the work on this volume of Management Revue, a Special Issue on Green HRM was published in ZfP (Zeitschrift für Personalforschung) in 2011 and an edited volume is under way on the role of HRM in developing economically, socially and ecologically sustainable organizations, in making HRM systems themselves sustainable and on the international dimension of Sustainable HRM and different cultural context of application (Ehnert, Harry \& Zink, forthcoming).

The EM, CS, HRM and CSR perspectives of the initial works influenced this pioneering phase of Sustainable HRM research. From the EM perspective, the focus is on ecological sustainability, from the CS perspective, the focus is on integrating economic, social and ecological sustainability but human resources sustainability is often neglected, from the HRM perspective the focus is on human sustainability and from the CSR perspective the focus is on social responsibility, . The reason for this diversity in the debate on Sustainable HRM lies in the historical development of the disciplines of origin and in different interpretations on the notion and nature of sustainability. For example, the academic areas CS and CSR have an overlapping core but are still distinctive and HRM is an area with a strong focus on financial performance and has (with exception perhaps from critical authors) considerable difficulties in thinking about sustainability as a real paradigmatic change as proposed by Gladwin and colleagues (1995). 
The global problems, however, are pressing companies to move forward in adopting and adapting a sustainability approach (that suits them), sustainability is about to become integrated in more and more university programs, not least in business schools (see the special issue in Academy of Management Learning \& Education, 2010, Vol. 9, No. 3), and Sustainable HRM is being established in higher education. For example, in the UK, the University of Stirling offers a post-graduate degree including a course on Sustainable HRM, in Belgium at the University of Antwerp Sustainable HRM is being taught as an executive Masters, in Austria Sustainable HRM is taught at the VU Vienna, in Germany at the University of Bremen Sustainable HRM is a distinct course in the Master for Business Psychology, and the University of Saarland offers an HR-Master including sustainability - to name just an few - and we expect further universities to follow.

An overview on these developments shows that sustainability has the potential to become an important topic for HRM. However the concept has rarely been applied systematically in conceptual research and empirical research is scarce. In addition, few authors make an effort to show commonalities and differences between the emerging works which might cause confusion to those who wish to make a contribution to the field. As described before, defining and clarifying sustainability are critical aspects and applying the concept in a meaningful way to HRM is even more challenging. We believe that finding ways to manage organizations sustainably with regard to their human/social, natural and economic resources is a major trial for HRM along with internationalization, globalization and resistance to globalization and that the idea of sustainability provides potential to strive for solutions which will meet these challenges. We also believe that HRM practice and research can have a major role in this - if they wish - because we see sustainability as a topic of strategic importance for HRM. And this is why, when planning this Special Issue, we called for contributions to the emerging literature on Sustainable HRM.

\section{Overview of this special issue}

In spite of our efforts to raise interest from authors working in the field and despite the encouraging developments, we found that much of the work on Sustainable HRM is still at early stages of study or still being developed. However, we have the pleasure of introducing the reader to three articles selected for this Special Issue contributing to the growing body of research on Sustainable HRM and to an extended book review in the form of an essay discussing one of the key sources from sustainable works systems inspiring some work on Sustainable HRM. The overarching theme of the contributions is the search for the role of HRM in implementing sustainability in organizations and in making HRM systems themselves sustainable.

The first article by Arjan Kozica and Stefan Kaiser titled 'A Sustainability Perspective on Flexible HRM: How to Cope with Paradoxes of Contingent Work' discusses the potential of Sustainable HRM to contribute to viewing research on flexible HRM in a somewhat different light, namely, not distinguishing managerial vs. non-managerial or hard vs. soft perspectives but integrating the views on positive and negative effect of flexible HRM into a common framework. The authors discuss the concept of Sustainable HRM as overcoming the limitations in previous flexible HRM research, as providing 
ideas about how to frame and cope with positive and negative effects of flexible HRM, as a possibility to link flexible HRM to a larger societal and ethical debate and as a concept to make paradoxical tensions both visible and manageable for HRM. The authors conclude by illustrating the means for Sustainable HRM to be used to understand how flexible HRM copes with or avoids paradoxical tensions and they suggest advancing with further holistic and integrative research.

The contribution of Stefanie App, Janina Merk and Marion Büttgen entitled 'Employer Branding: Sustainable HRM as a Competitive Advantage in the Market for High-Quality Employees' suggests why and how Sustainable HRM can help employers in creating an employer brand and thus support organizations to become the employer of choice compared to competitors. Building their arguments on signaling theory, social identity theory and person-organization fit, the authors link Sustainable HRM to the employer brand and argue that Sustainable HRM can be used to attract and retain highly qualified and motivated employees. In contrast to traditional talent management or employer branding approaches, the authors view not only the period of employment but also the time before and after employment-substance-oriented approach.

The third article by Bettina Lis is 'The Relevance of Corporate Social Responsibility for a Sustainable Human Resource Management: An Analysis of Organizational Attractiveness as a Determinant in Employees' Selection of a (Potential) Employee'. Lis explores the relationship between CSR and sustainability in the context of HRM. She looks at job seekers' perceptions of CSR and, perhaps without knowing, the potential employers attractiveness in terms of sustainability. Lis considers the influence of four dimensions of CSR with a view to developing greater understanding of their bearing on the attractiveness of the potential employer. Her article also adds weight to the argument that organizations can use Sustainable HRM practices to become an employer-of-choice.

Finally, we draw the reader's attention to the review article. Keith Jackson assesses the book by Peter Docherty and colleagues on Creating Sustainable Works Systems which was published initially in 2002 with a second edition in 2009. The literature on sustainable works systems has inspired research in the area of Sustainable HRM and there continues to evolve a fruitful interdisciplinary discourse between the two areas (see e.g., Ehnert et al., forthcoming). In his review, Jackson discusses the gaps between promises and delivery - especially from the very types of international bodies which created the Brundtland Commission. The lack of clear, agreed, definitions of sustainability add to the confusion of academics and practitioners in trying to conduct research or put into action the, laudable, aims of developing and implementing more sustainable ways of working. Jackson argues that the debate on how (and why) to be sustainable can question the fundamental purpose of a business and organization.

The papers in this special issue on Sustainable HRM provide us with useful ideas on the ways that sustainability can be applied in meaningful ways to HRM and how our contemporary approaches to HRM can be challenged by the notion of sustainability. The papers reveal that more, especially younger, academics are attracted to making a contribution to studying the role of HRM in developing sustainable organizations and in making HRM systems sustainable. This attraction is not surprising because the younger generations are the ones which will experience the greatest impact of unsustainable activities in ecological and socio-economic systems. As these papers address 
only a part of what we think is worth exploring on Sustainable HRM, suggests of further ideas for future research are given in the remainder of this introduction.

\section{Future directions for Sustainable HRM}

In this Special Issue we highlight the view that Sustainable HRM has the potential to become a new field for HRM research. In practice, there are many problems which have not been solved such as how organizations can become more sustainable, can make their HRM (and other sub-systems) sustainable, can co-exist within their social and ecological environments instead of overexploiting them and how HRM practices and strategies can become a core function in this changing set of circumstances. Recognizing that many authors now use the term Sustainable HRM in practice, teaching and research, we believe that this is an important emerging area of inquiry. Certainly, the topic does not yet have the clear lines and directions of more mature areas of study but academics, practitioners and especially, students see that the subject is of substantial importance. We are aware that there is no 'consistent' literature on Sustainable HRM. We also see different approaches to both sustainability and HRM with their origin in diverse contexts and disciplines and we do not think that there will soon be a consistency within the emergence of this area but instead we predict a plurality of competing approaches. In the same way as there is no longer one unchallenged way of measuring organizational effectiveness we consider it an advantage that there be a diversity of ways of examining this topic. Applications in practice and in future research will show which conceptualizations are more helpful to solve practical problems, to guide critical reflection on HR and whether Sustainable HRM indeed becomes a more widely accepted, applied and meaningful concept or whether there are compelling barriers in practice and in research which prevent the further development of a dedicated topic rather than subsume within other areas of research and practice.

In the context of this Special Issue, we point out possible routes for research on the role of HRM in initiating or implementing sustainability strategies in organizations and on the role of HRM in developing functional systems which are sustainable- areas which we believe would be especially fruitful for future conceptual and empirical research.

\section{Research on the role of HRM in initiating or implementing sustainability strategies}

Prior research on the role of HRM in implementing or even initiating sustainability strategies is relatively rare (see also Cohen, Taylor, \& Muller-Camen, 2012). However, several authors have argued that both sustainability and CSR initiatives in organizations do have direct relevance for the HRM field and therefore need to be considered both in HRM practice and in research (e.g., Clarke, 2011). This, however, is not the only reason for dealing with this subject. The topic is also important in the context of maintaining and fostering the HRM function's strategic role in the organization (Ehnert, 2009a). Ecological, social and economic sustainability seems as if it will be one of the most important challenges for organizations in the $21^{\text {st }}$ century and people in organizations are those who need to initiate, implement and welcome new and viable strategies and practices. Therefore, people management and HRM can play a key role in guiding these transformations and change processes while not leaving this to 
CSR and environmental sustainability functions. Research on the role of HRM in initiating and implementing sustainability strategies and practices is complex as we, and the contributors to this edition, have shown. This research involves multiple dimensions of sustainability, multiple levels of analysis, while needing to consider both local and global scopes with short- and long-term effects whilst knowledge of multiple disciplines is essential for advancing the field of study.

\section{HRM and multiple dimensions of sustainability}

We understand that since the Brundtland Commission's report, many actors link the idea of sustainability to at least three dimensions (economic, social and ecological sustainability). Nevertheless some authors (e.g., Pfeffer, 2010) have emphasized the importance of a fourth dimension- human sustainability. Prior research on Sustainable HRM has often looked at two or three rather than all four sustainability dimensions (e.g., either the economic and ecological or the economic and social dimensions). Although, we have argued, a variety of ways of considering and defining sustainability is useful at this stage in the development of study we do believe that there needs to be more effort to produce sound and clear definition(s) of the term 'sustainability' even if a series of sub-definitions results under a broad banner. Without such efforts to define the term it can be used and abused as a means of 'green-washing' organizational objectives and actions so become devalued and ignored. This would be a sad consequence of the absence of agreement on characterizing a concept which is definitely of great importance.

In addition, if sustainability and holistic thinking (in terms of economic, ecological, social and human sustainability) are to be taken seriously, there needs to more HRM research looking at multiple dimensions simultaneously because it is likely that complex, non-linear interdependencies between different sustainability dimensions require to be considered (Ehnert et al., forthcoming). For example, organizations need a much better understanding around whether implementing Sustainable HRM can foster or perhaps even inhibit 'greening' activities in the organization (or vice versa whether 'greening' of the organization can impact on the way that people are managed). Other examples include how Sustainable HRM can contribute to developing a 'sustainability mindset' in the organization, about the interrelations between human and ecological sustainability etc. For future HRM research, it is important to explore the role of the function in commencing, measuring, assessing and guiding sustainability initiatives in multiple dimensions.

\section{Sustainable HRM in the global context}

Internationalization and globalization play a major and increasing role in management and HRM practice and research. International HRM and comparative HRM have emerged as strong areas of research with high practical relevance. It is particularly necessary that those with a grounding in research and practice in developed economies consider the role of sustainability within emerging (and not yet emerging) economies where, for very many people, day to day survival is more important than thinking of future benefit. For people in the UK, for example, whose ancestors destroyed native forests to build warships or create pasture for sheep farming to tell those in the tropics to not cut down rain forest because this action will harm humanity and the envi- 
ronment can be seen as hypocritical. Instead reasons for more sustainable approaches have to be considered and justified in terms which are relevant to the local, as well as global, context so attention can be drawn to the serious consequences for the future generations of overexploitation of resources or examples of poor practices such as those in the UK can be admitted and in future avoided. We must also not fall into the trap of believing that every society or economy will develop in the same way as those of the European Union or North America (see Ehnert et al., forthcoming). As we see in the papers within this edition even exploring the topic of sustainability and HRM is very difficult within national boundaries (where single sets of laws and limited ranges of practices occur) so we can understand that when we deal with sustainability across borders, especially between rich and poor, the challenges are multiplied and complexity increased.

It is therefore not surprising, that scholars also advocate including an international dimension into research on Sustainable HRM (e.g. Jackson et al., 2011). We strongly support this call for additional research considering the international dimension of HRM for three reasons. First, especially multinational, organizations face increasing pressures from investors and other stakeholders to report on their environmental and social performance in addition to their economic performance (KPMG, 2011; Litvin, 2003). As a consequence, ecological and social performance indicators such as those from GRI (Global Reporting Initiative) play an increasingly important role and also affect core HRM issues (e.g., Ehnert et al., 2010).

Second, the overall debate on sustainability and CSR is characterized by values and assumptions that might not be shared in the same way everywhere in the world (Ehnert, 2009a). For example, the notion of 'long-term' that is constitutive for research about sustainability can be interpreted differently across different cultures (Smith \& Bond, 1998; Shweder, 2003). Also, the sustainability debate addresses values in the relationship of human beings to their environment -e.g. to live in harmony with or dominate the environment. These values are not shared everywhere, especially when the need for more economically and socially sustainable business behavior is abused (Hiatt, 2007) or is not widely accepted (Emmott, 2008).

Third, it is likely that MNEs increasingly face paradoxes, dilemmas and tensions in their supply chains with regard to managing human resources in a sustainable way. For example, one of the questions frequently asked is 'should organizations implement Sustainable HRM for home country employees only or also for the 'cheaper' workforce in developing countries?'. Questions to be addressed in future research could include "what is the role of HRM in sharing resources across borders and across generations?' (Collier, 2010), which sustainability indicators are relevant from an HRM perspective and how could these be integrated in HRM practices (such as reward), (Harry, in Ehnert et al., forthcoming).

\section{Sustainable HRM and multiple levels of analysis}

Following our understanding of Sustainable HRM, multiple levels of analysis are relevant for future research. At a macro level of analysis, sustainability refers to a sustainable societal development and is relevant for business organizations when considering the viability of systems which deliver critical resources on which the organization and 
HRM depend is concerned, when organizational legitimacy is at risk and HRM is made responsible for this potential (for example because of having recruited staff who then abuse resources or act illegally) and when certain HRM practices and strategies foster unsustainable and irresponsible behavior of people in the organization. Future research could address questions on the impact of specific HRM practices and strategies on the ecological, social, human and economic sustainability with interrelations to society and potentially include questions of intra- and intergenerational justice and resource allocations.

At a meso level of analysis, sustainability refers to the development of sustainable organizations, work and HRM systems. Research could tackle the hypothesis that in order to realize economically, socially and ecological sustainable organizations, sustainability also needs to be realized in organizational sub-systems such as HRM. One potential line of enquiry would be whether all HRM sub-functions need to be both efficient and sustainable or if organizations can be sustainable if some entities or subfunctions follow the logic of efficiency and others follow the logic of sustainability. Finally, sustainability at the individual level of analysis generally refers to human sustainability which could be defined as the capacity to regenerate and develop discrete human resources. Future research may usefully address questions such as how sustainability at the individual level affects overall HRM and organizational sustainability (and vice versa).

\section{Research on the role of HRM in developing Sustainable HRM systems}

Two articles in our Special Issue, the article by Bettina Lis and the article by Stefanie App and her colleagues have focused on the relevance of Sustainable HRM practices and strategies in developing a positive employer brand and becoming an employer of choice. As, especially, the younger generation of talents seems to be highly aware of the necessity for organizations to learn how to deal with resources in a more sustainable, regenerative and nourishing way, it is a logical consequence that more and more candidates are searching for jobs that allow them to act according to their values at work and not keep such values solely for their private lives. As a consequence examples of the relevant Sustainable HRM practices to be studied include work-life-balance support, employee health and well-being related activities, along with actions which demonstrate employer responsibility towards employees (and perhaps vice versa).

\section{Sustainable HRM practices and strategies for attracting and retaining talent}

Future research needs to address what kind of Sustainable HRM practices and strategies are recognized and valued by employees working in organizations and by those potentially interested in a position and under which conditions Sustainable HRM is effective. As App and colleagues have shown, the whole employee life span is of interest for this analysis, including the time before a person enters and after they leave an organization. Second, the overlap between CSR practices (including more normative, political elements such as corporate volunteering or like those promoted by the International Labour Office (ILO) such as human rights or democratic elements in labor relations) and Sustainable HRM practices would be useful to explore. For example which practices are, perceived as being, sustainable and for which groups of stake- 
holders? Third, as Sustainable HRM is not only interested in studying effects at one point in time but more on a longitudinal basis, additional questions could address the long-term impacts of Sustainable HRM practices and strategies and how these activities evolve over time.

\section{Sustainable HRM practices and strategies for a healthy workplace}

From an employer perspective, Sustainable HRM is not only relevant for attracting and retaining talent, but also more generally for maintaining a healthy and productive workforce (Ehnert, 2009a). This is especially relevant in contexts where organizations face the consequences of aging workforces or a lack of young talent due to demographic developments or decisions on reducing resources devoted to education or training. Similar to the research on sustainable work systems, the literature on Sustainable HRM needs to explore what kind of HR activities are detrimental to human health and what kind of activities foster a healthy employee lifestyle. These questions are particularly interesting as in some industries we face the situation that much of the work is not undertake by permanent employees but by contingent employees- such as agency staff, short term workers or those employed by outsource service providers. Some of these contingent staff are independent contractors with high levels of capability and high rates of pay working at their own risk and responsibility (e.g., highly skilled employees in the ICT industry). However, the majority of contingent staff are agency workers or subcontractors (e.g., low skilled employees in the food industry filling in supermarket shelves) who have much poorer pay and conditions than the permanent staff. The use of contingent workers is often accomplished by extending privileges to permanent staff who are protected from great changes in the economy or society - for example older workers in the public sector in some Mediterranean countries of the European Union whose employment is virtually guaranteed while younger entrants to the workplace cannot get jobs because employers cannot afford to pay for new staff along with those on 'legacy' contracts and superior conditions of service. Meanwhile restrictions on trade leads to jobs being created or maintained in rich countries while people in poorer countries, capable of undertaking the work and willing to work for lower pay and benefits, are unemployed. Such issues raise not only ethical questions about who profits from Sustainable HRM practices but also questions about how employment needs to be designed so that people are not exploited (or exploit themselves) but instead are supported in fostering a healthy work practices and lifestyle. These and further topics will be of interest for future research on Sustainable HRM.

\section{Conclusion}

Sustainability is likely to become a core theme for management research in the future. As practitioners and scholars are coming to agreement that sustainability is of importance, including for HRM, there will probably be divergent views about the dominant definitions and interpretations of sustainability, about which aspects of the organization and HRM the term sustainability refers to, how a Sustainable HRM can be implemented and about the ethical or social responsibility aspects of Sustainable HRM. The papers in this special issue show that the application of the sustainability concept is not only possible, but that it provides new answers to old questions - espe- 
cially if we are prepared to re-think basic assumptions about our economic systems. As we have discussed the debate also raises new questions to be answered! In our view, HRM could play a vital role in implementing a 'sustainability mindset' in business organizations. We are, however, just of the beginning of this development process.

All contributions in this special issue provide us with ideas and thought provoking views on how to re-think the HRM discipline from the perspective of sustainability. We believe that despite the frequent use (and misuse) of the term, the trend towards making organizations more sustainable and contributing to an overall sustainable development in societies across the globe is one of the key challenges for the $21^{\text {st }}$ century - if not the challenge for mankind.

In this special issue, we argue that many of us, including decision-makers in HRM, are tempted to postpone choices and actions to sometime in 'the future'. In 'the future', however, choices might become more painful for all involved or even be irreversible if we look, for example, at the loss of biodiversity. If we imagine the consequences of emerging economies consuming the same amount of resources as the wealthy in industrialized nations or if we look at the current difficulties in the European economic system we see that some decisions and actions cannot, gainfully be postponed to 'the future'! We also argue that by procrastinating these choices instead of 'integrating the future into the present' (Evans \& Génadry, 1999), organizations, and especially HRM, lose not only important potential but that producing beneficial change becomes more difficult in 'the future'. We might shrug our shoulders and accept that 'the world is like this'. In the business world, especially, it may seem risky to be a trailblazer so it is tempting to wait for others. Yet it is through innovation that humanity has, hitherto, been successful so we could start thinking about viable alternative ways of doing business and of managing people in organizations. Future research on Sustainable HRM can help describing, analyzing, explaining and discussing the role of HRM in making HRM and work systems sustainable. Enjoy this special issue and use it as a source of inspiration for embarking on your own sustainability journey.

\section{Acknowledgements}

This special issue would not have been possible without the support of the main editor of Management Revue, Wenzel Matiaske, who has been open for the novel topic of Sustainable HRM and very supportive throughout the whole process of publishing. We would like to thank the anonymous reviewers who have supported the authors in sharpening their contributions and the authors themselves for their engagement.

\section{References}

Bansal, P. (2005). Evolving sustainably: A longitudinal study of corporate sustainable development. Strategic Management Journal, 26, 197-218.

Beer, M., Spector, B., Lawrence, P. R., Mills, D.Q., \& Walton, R. E. (1984). A conceptual view of HRM. Managing Human Assets. New York: Free Press.

Boudreau, J. W.; Ramstad, P. M. (2005). Talentship, talent segmentation, and sustainability: A new HR decision science paradigm for a new strategy definition. Human Resource Management, 44(2), 129-136.

Litvin, D. (2003). Empires of profit: Commerce, conquest and corporate responsibility. New York: Texere.

Clarke, M. (Ed.) 2011). Readings in HRM and sustainability. Tilde: University Press. 
Cohen, E. (2010). CSR for HR: A necessary partnership for advancing responsible business practices. Sheffield: Greenleaf.

Cohen, E., Taylor, S., \& Muller-Camen, M. (2012). HRM's role in corporate social and environmental sustainability. SHRM Report.

Collier, P. (2010). Plundered planet. London: Allen Lane.

Costanza, R., Daly, H. E., \& Bartholomew, J. A. (1991). Goals, agenda and policy recommendations for ecological economics. In R. Costanza (Ed.), Ecological economics: The science and management of sustainability (pp. 1-20). New York: Columbia University Press.

de Woot, Ph. (2005). Should Prometheus be bound? Corporate global responsibility. London: Palgrave Macmillan.

Docherty, P., Forslin, J., Shani, A. B., \& Kira, M. (2002). Emerging work systems: from intensive to sustainable. In P. Docherty, J. Forslin, \& A.B. Shani (Eds.), Creating sustainable work systems. Emerging perspectives and practice (pp. 3-14). London: Routledge.

Docherty, P., Kira, M. \& Shani, A. B. (2009). What the world needs now is sustainable work systems. In: P. Docherty, M. Kira, \& A. B. Shani (Eds.), Creating sustainable work systems. Developing social sustainability (pp. 1-21), 2nd edition. London: Routledge.

Dyllick, T., \& Hockerts, K. (2002). Beyond the business case for corporate sustainability. Business Strategy and the Environment, 11, 130-141.

Ehnert, I. (2012). Nachhaltiges Personalmanagement: Konzeption und Implementierungsansätze. In S. Kaiser \& A. Kozica (Eds.), Ethik im Personalmanagement: Zentrale Konzepte, Ansätze und Fragestellungen, 131-157. München u. Mering: Hampp.

Ehnert, I. (2011). Sustainability and Human Resource Management. In A. Wilkinson \& K. Townsend (Eds.), The future of employment relations (pp. 215-237). Palgrave.

Ehnert, I. (2010). Nachhaltigkeit im HR-Management: Spannungen aushalten, Widersprüche bewältigen. Personalfübrung, 42(5), 26-36.

Ehnert, I. (2009b). Sustainability and Human Resource Management: Reasoning and applications on corporate websites. European Journal of International Management, 3(4), 419-438.

Ehnert, I. (2009a). Sustainable Human Resource Management: A conceptual and exploratory analysis from a paradox perspective. Heidelberg: Physica-Verlag.

Ehnert, I. (2008). Strategien und Praktiken eines Nachhaltigen Human Resource Management. Umwelt Wirtschaftsforum (uwf), 16, 187-192.

Ehnert, I. (2006). Sustainability issues in Human Resource Management: Linkages, theoretical approaches, and outlines for an emerging field. Paper prepared for 21. EIASM SHRM Workshop. Birmingham: Aston.

Ehnert, I., Harry, W., \& Zink, K. (Eds.). (forthcoming). Handbook of sustainability and Human Resource Management. Springer, planned for publication in late 2012.

Ehnert, I., Muller-Camen, M., Parsa, S., \& Roper, I. (2010). The sustainable business and Human Resource practices: What is the link? Kommission Personalmanagement der Hochschullehrer für Betriebswirtschaft, Gießen, November 11-12.

Elkington, J. (1994). Towards the sustainable corporation: Win-win business strategies for sustainable development. California Management Review, 36(2), 90-100.

Emmott, B. (2008). Rivals: How the power struggle between China, India and Japan will shape our next decade. London: Allen Lane.

Evans, P., \& Génadry, N. (1999). A duality-based prospective for strategic Human Resource Management. In P. M. Wright, L. D. Dyer, J. W. Boudreau, \& G. T. Milkovich (Eds.), Research in Personnel and Human Resoure Management. Supplement 4 (pp. 367-395). Greenwich, CT: JAI Press,.

Gladwin, T. N., Kennelly, J. J., \& Krause, T. S. (1995). Shifting paradigms for sustainable development: Implications for management theory and research. Academy of Management Review, 20(4), 874-907.

Gollan, P. (2005). High involvement management and human resource sustainability: The challenges and opportunities. Asia Pacific Journal of Human Resources, 43, 18-33.

Gollan, P. (2000). Human resources, capabilities and sustainability. In D. Dunphy, J. Benveniste, A. Griffiths, \& P. Sutton (Eds.), Sustainability - The corporate challenge of the 21st century (pp. 55-77). Sydney: Allen and Unwin.

Guerci, M. (2011). La gestione delle risorse umane per la sostenibilità dell'impresa. Franco Angeli. 
Hahn T., \& Figge F. (2011). Beyond the bounded instrumentality in current corporate sustainability research: Toward an inclusive notion of profitability. Journal of Business Ethics, 104, 325-345.

Harry, W. (forthcoming). The relevance of the vision of sustainability to HRM practice. In I. Ehnert, W. Harry, \& K. Zink (Eds.) (forthcoming). Handbook of sustainability and Human Resource Management, Springer, planned for publication in late 2012.

Hiatt, S. (Ed.) (2007). A game as old as empire. San Francisco: Berrett-Koehler.

Jabbour, C. J. C., \& Santos, F. C. A. (2008). The central role of human resource management in the search for sustainable organizations. International Journal of Human Resource Management, 19(12), 2133-2154.

Jackson, S. E., Renwick, D. W. S., Jabbour, C. J. C., \& Muller-Camen, M. (2011). State-of-the-art and future directions for green Human Resource Management: Introduction into the special issue. Zeitschrift für Personalforschung, 25(2), 99-116.

Jackson, S. E., \& Seo, J. (2010). The greening of strategic HRM scholarship. Organization Management Journal, 7(4), 278-290.

Kira, M. (2002). Moving from consuming to regenerative work. In P. Docherty, J. Forselin, \& A. B. Shani (Eds.), Creating sustainable work systems. Emerging perspectives and practice (pp. 29-39). London: Routledge.

KPMG (2011). International survey of corporate responsibility reporting. Publication number: 110973. November Zurich: KPMG-

Mariappanadar, S. (2012a). Harm of efficiency oriented HRM practices on stakeholders: An ethical issue for sustainability. Society and Business Review, 7(2), 168-184.

Mariappanadar, S. (2012b).The harm indicators of negative externality of efficiency focused organizational practices. International Journal of Social Economics, 39(3), 209-220.

Mariappanadar, S. (2003). Sustainable Human Resource strategy: The sustainable and unsustainable dilemmas of retrenchment. International Journal of Social Economics, 30(8), 906-923.

Moldaschl, M., \& Fischer, D. (2004). 'Beyond the management view.' A resource-centered socioeconomic perspective. Management Revue, 15(1), 122-152.

Muller-Camen, M., Hartog, M., Morton, C., et al. (2008). Corporate social responsibility and sustainable HRM. In M. Muller-Camen, R. Croucher, \& S. Leigh (Eds.), Human Resource Management: A case study approach (pp. 467-488). London: CIPD.

Müller-Christ, G. (2001). Nachhaltiges Ressourcenmanagement. Marburg: Metropolis-Verlag.

Müller-Christ, G., \& Remer, A. (1999). Umweltwirtschaft oder Wirtschaftsökologie? Vorüberlegung zu einer Theorie des Ressourcenmanagements. In E. Seidel (Ed.), Betriebliches Umweltmanagement im 21. Jabrbundert. Aspekte, Aufgaben, Perspektiven (pp. 69-87). Berlin: Springer,.

Pfeffer, J. (2010). Building sustainable organizations: The human factor. Academy of Management Perspectives, 2, 34-45.

SHRM (2011). Advancing sustainability: HR's role. A research report by the Society for Human Resource Management, BSR and Aurosoorya. SHRM.

Scholz, C., \& Müller, S. (2010). Kompetenə4HR: Nachbaltigkeit in der Personalarbeit in Österreich. Saarbrücken: Institut für Managementkompetenz.

Shrivastava, P. (1995). The role of corporations in achieving ecological sustainability. Academy of Management Review, 20(4), 936-960.

Shweder, R. A. (2003). Why do men Barbecue? Recipes for cultural psychology. Cambridge Mass: Harvard University Press.

Smith, P. B., \& Bond, M. H. (1998). Social psychology across cultures. Hemel Hempstead: Prentice Hall.

WCED (World Commission on Environment and Development) (1987). Our common future: Report of the World Commission on Environment and Development. Brussels.

Wilkinson, A. (2005). Downsizing, rightsizing or dumbsizing? Quality, Human Resources and the management of sustainability. Total Quality Management, 16(8-9), 1079-1088.

Wilkinson, A., Hill, M., et al. (2001). The sustainability debate. International Journal of Operations \& Production Management, 21(12), 1492-1502.

Zaugg, R.J. (2009). Nachbaltiges Personalmanagement: Eine neue Perspektive und empirische Exploration des Human Resource Management. Bern, Wiesbaden: Gabler.

Zaugg, R. J., Blum, A., et al. (2001). Sustainability in Human Resource Management. Working paper No. 51, Institute for Organisation und Personel. Bern: University of Bern.

Zink, K. J. (2008). Nachhaltigkeitsstrategien und Human Resource Management. In M. von Hauff, V. Lingnau, \& K. J. Zink (Eds.), Nachbaltiges Wirtschaften (pp. 193-211). Baden-Baden: Nomos. 